\title{
ФОНАЦІЙНІ ФРАЗЕОЛОГІЗМИ ЯК ХАРАКТЕРИСТИКА МАНЕРИ ВИСЛОВЛЮВАТИСЯ (ОСОБЛИВОСТІ ФОНАЦІЇ, ГОЛОСУ, ІНТОНАЦІЇ)
}

Величко Г. Г. Фонаційні фразеологізми як характеристика манери висловлюватися (особливості фонації, голосу, інтонації).

У статті розглянуто особливості фонаційних фразеологічних одиниць як характеристику манери висловлюватися, зокрема увага зосереджується на таких поняттях як „сила голосу”, „тон”, „інтонація”; визначається взаємозв’язок між одиницями вербального i невербального рівнів комунікації, наголошується на емоційності висловів такого типу, їхній комунікативній цінності.

Ключові слова: фразеологізм, інтонація, голос, фонація.

Величко А. Г. Фонационные фразеологизмы как характеристика манеры говорить (особенности фонации, голосу, интонации).

В статье рассматриваются особенности фонационных фразеологических единиц как характеристика манеры говорить, в том числе внимание обращается на такие понятия: „фонация”, „сила голоса”, „интонация”, определяется взаимосвязь между единицами вербального и невербального уровней коммуникации, делается акцент на эмоциональность выражений такого типа, на их коммуникативную ценность.

Ключевые слова: фразеологизм, интонация, голос, фонация.

Velychko H. H. Phonation phraseologisms as characteristics of manner of speaking (peculiarities of phonation, voice and intonation).

The article deals with peculiarities of phonation phraseological units as the characteristics of manner of speaking. The author pays attention to such notions as "phonation", "voice intensity", "intonation", determines the correlation between the units of verbal and non-verbal communication levels and underlines an emotionality of such expressions and their communicative values.

Key words: phraseologism, intonation, voice, phonation.

Фонація як явище загалом фізичне, пов'язана з усіма властивостями голосового апарату людини, виявляє ті ознаки, що властиві передовсім мовцю як індивіду. При дослідженні властивостей мовної фонації ми насамперед виявляємо можливість розгляду проблеми в чотирьох аспектах.

Перший аспект $є$ мовним, тому що він пов'язаний із вивченням артикуляції мовних одиниць і стосується компетенції власне лінгвістики.

Другий аспект стосується вивчення артикульованої мови, але не окремих звуків, а суперсегментних відрізків, до яких належать насамперед інтонація і фразовий наголос. Цей аспект, як і перший, розглядається у сфері власне лінгвістики.

Третій аспект передбачає дослідження артикуляції як деякої просодичної ознаки, що виявляє загальні умови комунікації (виявлення таких ознак конкретного процесу комунікації: упевненість або сумнів, 
грубість або делікатність мовця і т. ін.). У кожному мовному колективі створюється певний стереотип цих просодичних ознак комунікації, що входить у поняття комунікації як деяка підсистема на кшталт підсистеми жестів, міміки, але 3 функцією не структурного оформлення висловлювання, а передачі певного фонаційного стереотипу надфразового характеру. Цей третій аспект - маргінальний випадок паралінгвістичного використання фонаційних можливостей людини.

I нарешті, четвертий аспект - дослідження мовної фонації як психофізичного явища, в основі якого найважливішим компонентом виступають особливості голосу; ці явища не стосуються мовної артикуляції й виявляють лише психофізичний стан мовця (роздратування, знервованість) [3, с. 43-44].

Мета статті: визначити своєрідність фонаційних фразеологізмів української мови як характеристику манери висловлюватися; охарактеризувати особливості тону, голосу, інтонації як домінанти в семантиці стійких виразів.

Голосові характеристики, маючи за основу психологічну реальність, постають корелятами людських характерів, почуттів, індивідуальних та соціальних міжособистісних стосунків, різноманітних поведінкових реакцій. Ці співвідношення $є$ надстійкими, що сприяє утворенню у свідомості людей стереотипних уявлень про форми прояву емоцій, про розподіл інтерперсональних ролей та про структури поведінки, які відображені в мовленнєвій просодиці [4, с. 223]. Подібні стереотипи зафіксовані у відповідних моделях комунікації та стійких одиницях мови.

Фонаційні засоби в паралінгвальному плані визначити набагато складніше, ніж інші невербальні компоненти. За своїми функціями вони наближаються до умовних індексів. У різних культурах існують певні асоціації між якісними властивостями голосу й особистісними характеристиками комунікантів або їх почуттями та емоціями: порівняйте, наприклад, інтерпретації високого і низького голосу, хриплого і чистого безвідносно до змісту вербальних висловів. Фонаційні засоби найбільш тісно пов'язані 3 вербальними засобами - фактично вони „озвучують” слова в мовному контексті, додають висловам комунікативну завершеність і виразність, і в цьому складність виявлення їхніх власних функцій. До таких належать:

1) соціально-інформаційна - за допомогою акцентних та інших особливостей вимови актуалізуються ознаки соціального статусу комунікантів, демографічних характеристик та оцінної орієнтації;

2) оцінна - виражається за допомогою логічного наголосу і тону (при цьому вербальний вираз оцінки може не відповідати тону навмисне або ненавмисне);

3) емотивна - виражається за допомогою гучності, висоти голосу, паузи, зітхання, темпу, а також за допомогою вокалізаторів невербалізованих звуків на зразок „мм-мм”, „е-е”, „гм”; 
4) регулювальна - виражається за допомогою пауз, що сигналізують про початок, продовження або завершення вислову, про очікування у відповідь репліки. Визначити чітко, які функції закріплені за певним фонаційним засобом, складно, тому що здебільшого їхні компоненти використовуються одночасно, наприклад, тон і характерна властивість голосу. Але природні властивості голосу мають суб'єктивну інтерпретацію, як і темп. „Навантаженим” у функціональному плані $є$ тон, який здатний передавати різноманітні ознаки оцінної інформації. Відзначено, що за тоном краще розпізнаються емоції страху і гніву, але слабо розрізняються такі почуття, як любов і печаль, гордість i задоволеність. У межах вислову вербальні та фонаційні засоби функціонують синхронно, i це зумовлює їхню тісну взаємодію в інтерпретації смислової й оцінної інформації. Знання прийнятих у суспільстві норм цієї взаємодії складає частину когнітивного аспекту фонаційних засобів [3, с. 58].

На основі манери висловлювання, особливостей сили голосу, тону, інтонації ми можемо виокремити такі фонаційні ФО: [ŭ] голосу не відводити (5, с. 97); на весь (на повний / у повний) голос (5, с. 159); [i] голосу не відтягне (5, с. 107); розпускати голос (5, с. 613); піднімати (nідіймати, підносити i m. ін.) / підняти (підійняти, піднести $і$ т. ін.) голос (5, с.510); зриватися з голосу (5, с.272); давати / подавати голос [свій] (5, с.173); не своїм (нелюдським, несамовитим $i$ т. ін.) голосом (5, с. 160); відкривати рота (5, с. 102); дерти мовчака (5, с. 194); дерти горло (горлянку) (5, с. 194); дерти рота (5, с. 195); дзвонити зубами (5, с. 196); зуб на зуб не потрапляе $(5$, с. 273); клачати зубами (5, с. 300); ковтати слова (5, с. 303); кресати словами (5, с. 312); лопотіти язиком

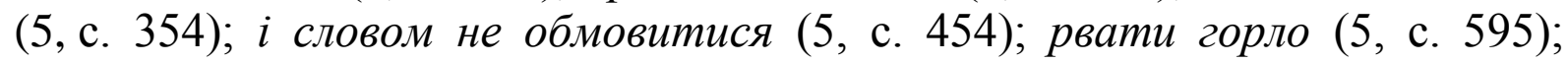
сипати словами як горохом (5, с. 647); стріляти словами (5, с. 698); ивіркати через губу (5, с. 756); рвати слова (5, с.595); цідити / процідити крізь зуби (5, с.757); цокотіти (цокотати, цокати) зубами (5, с. 758) та ін.

Своєрідність артикуляції людини полягає в тому, що, крім утворення одиниць комунікації за допомогою органів мовлення і голосу, у самому акті комунікації втілюються всі характеристики, властиві мовцю, що виявляються, окрім жестів і міміки, голосовими властивостями людини.

Артикуляція в широкому витлумаченні $\epsilon$ немовбито синтезом фонаційних моментів у процесі комунікації, і завдання лінгвістичного аналізу полягає не лише в тому, щоб досліджувати самі мовні форми, але й установити суттєві ознаки власної мовної артикуляції та відрізнити їх від ознак, властивих фонації.

Продукування мовленнєвого матеріалу не може здійснюватися без допомоги голосу. Він значною мірою зумовлений фізичним та емоційним станом мовця, його ставленням до співрозмовника та до змісту висловлювання. Фразеологічні одиниці, які зафіксували у своїй семантиці 
силу голосу: підіймати, (підносити і m. ін.) / підняти (підійняти, піднести i m. ін.) голос, [ü] голосу не відводити; на весь (на повний / у повний) голос; [i] голосу не відтягне; розпускати голос; зриватися з голосу; давати / подавати голос [свій]; не своїм (нелюдським, несамовитим $i$ m. ін.) голосом. Так, скажімо, вислів підіймати, (підносити $і$ m. ін.) голос означає „починати говорити, висловлювати свої думки; говорити голосніше, підвищувати тон", де семантичне навантаження на лексемі голос переноситься від значення „сукупність різних стосовно висоти, сили i тембру звуків, що їх видає людина (або тварина, яка дихає легенями) за допомогою голосового апарата” до, підкреслюємо, „висловлювати свою думку”, наголошувати на своєму „Я” i, нарешті, до такої характеристики як висота голосу (підвищувати тон). Приклад ілюструє нагромадження різних значень у структурі однієї мовної одиниці, яка їх консолідувала і тим самим набула не тільки паралінгвального „звучання”, але й ментального.

Фразеологізми розпускати голос та розпускати / розпустити губи тлумачаться так: „не стримуватися в розмові, говорити багато неприємного". Дієслово розпускати багатозначне; одне зі значень переносне ,послаблюючи вимогливість до кого-небудь, контроль за кимсь, дозволяти йому не стримуватися у виявленні своїх почуттів, настрою i т. ін.” і виправдовує негативну семантику стійких висловів. В українській культурі по губах ,угадують настрій, поведінку людини (губу закопилити означає „надутися, розсердитися”, „зазнатися”), іiі характер (розпустити губи „багато говорити, брехати, пліткувати”)” [1, с. 160]. Особливості фонації цього виразу, пов'язані з фізіологічними особливостями суб'єкта, можуть бути визначені контекстуально, лише за умов комунікації. Вони залежатимуть від його психічного стану i супроводжуватимуть мовну артикуляцію за участю губ. Передача інформації, а саме пліток, може відбуватися з різним інтонуванням: людина здатна лукавити, радіти, злитися, дивуватися, обурюватися і т. ін. Однак мовна одиниця передає лише загальний „настрій” ситуації спілкування - нестримність мовлення, втрату контролю, необдуманість.

Вислів дерти мовчака - „не протестувати, не заперечувати; мовчати” - використовується в разі повної нездатності говорити чи тимчасової втрати голосу, а дерти горло (горлянку) - у першому значенні „з великим напруженням кричати, галасувати, співати” є антонімічною парою.

Із загальнофонаційних ознак мовлення, частина 3 яких не має стосунку до мови як засобу артикуляції, тобто виробництва словесних комунікативних одиниць, необхідно виділити ще одну сферу, а саме інтонацію.

Інтонація у фоні логічного наголосу (тут можна розглядати логічний наголос як особливий інтонаційний засіб виокремлення члена речення) використовується в різних мовах по-різному, залежно від типу мови (аналітичний або синтетичний лад, розвинута відмінкова система). 
Особливим видом фонації, що супроводжує мовне висловлювання, $\epsilon$ характеристика суб'єкта не з погляду його фізичних даних, а 3 погляду несуб'єктних обставин [3, с. 39].

Відповідно до сучасного витлумачення проблеми емоційної інформації в мові дослідники визначають емоційну функцію інтонації, називаючи іï найчастіше експресивною 3 деталізацією. Наприклад, вислів зриватися з голосу, який означає „утрачати голос, замовкати від надмірного крику або хвилювання", фіксує виразну емоцію людини утрату емоційного контролю над собою, сильне емоційне напруження, стан фрустрації. Цілком очевидно, що вся царина експресивної інтонації функціонально не входить у внутрішню структуру мови, а $є$ надбудовною і не залучається до власне лінгвістичної проблематики.

Ученими експериментально встановлені акустичні параметри інтонації для вираження емоцій (гнів, печаль). Для гніву, скажімо, визначним параметром буде велика інтенсивність (рвати слова) Гнів пов'язують зі збудженням центрального ядра мигдалини і збільшенням змісту норадреналіну і тестостерону. Його еволюційне значення полягає в мобілізації енергії для активного самозахисту індивіда. 3 розвитком цивілізації ця роль гніву стала не такою важливою. Тому гнів і різний ступінь його прояву (злість як слабкий гнів і лють як сильний гнів) можна віднести до негативних афектів, хоч деякі дослідники розглядають його як засіб самозахисту (М. Мак-Кей) [2, с. 183]. Психофізіологічні процеси, які відбуваються в організмі за такого стану, підвищують упевненість у собі, зменшують страх перед небезпекою. Людина стає схильною до імпульсивних учинків, готова до нападу на джерело гніву або прояву агресії у вербальній формі, зокрема інтонаційним показником може слугувати велика інтенсивність, гучність вимовляння (зриватися з голосу), неприродна експресивність (не своїм (нелюдським, несамовитим і т. ін.) голосом).

Печалі властиві такі характеристики: 1) вузький мелодичний інтервал; 2) рівний мелодичний контур; 3) повільний темп; 4) слабка інтенсивність. Печаль викликається розлукою, психологічною ізоляцією (так званим відчуттям самотності) і невдачею в досягненні мети, розчаруванням, тобто нездійсненою надією. Як відзначає К. Ізард, „печаль, уповільнюючи загальний темп життя людини, дає їй можливість „озирнутися назад” [2, c. 184]. Уповільнення психічних i соматичних процесів, якими супроводжується емоція печалі, дозволяє інакше поглянути на світ. Для печалі характерні процеси, протилежні тим, які спостерігаються в радості: гальмування моторики, звуження кровоносних судин. Це викликає відчуття холоду й ознобу. Звуження дрібних судин легенів приводить до відтоку з них крові, у результаті погіршується надходження кисню в організм i людина починає відчувати нестачу повітря, утруднення i тяжкість у грудях. Прагнучи полегшити цей стан, вона починає робити 
тривалі і глибокі вдихи. Її рухи повільні, руки і голова опущені, голос слабкий, а мова уповільнена, розтягнута. Удалим прикладом $\epsilon$ фразеологічна одиниця давати / подавати голос [свій] - „видавати певні звуки, озиватися; висловлюватися на захист кого-, чого-небудь, на чиюсь користь", де відповідно до контексту можна витлумачити наявність певного емоційного забарвлення.

Інтонація подібних емоцій, як вираження немовної інформації, $\epsilon$ більш вузькою сферою звукової мови, і фахівці з інтонації відстоюють право займатися функцією інтонації в цьому плані.

Напевне, функціональний підхід до всієї царини фонації повинен бути спрямований на чітке відмежовування також i y сфері інтонації лінгвістичних особливостей від усіх видів нелінгвістичної інтонації як просодичних ознак, що стосуються немовної інформації, які нашаровуються на артикуляцію мови.

Емоційні чинники, що не стосуються безпосередньо внутрішнього змісту фрази, однак використовувані при висловлюванні, є показниками контексту комунікації, проте виходять за межі не тільки мовних засобів, але навіть паралінгвальних (переконаність, грубість, задушевність, презирство, гнів, радість і т. ін.). Вони не $є$ складовими частинами словесного висловлення, якщо не входять як елемент змісту у структуру.

Подібна фонація належить до власне екстралінгвістичних чинників, на основі яких слухач може робити висновки про настрій і стан мовця. Фонація за своєю функцією не $\epsilon$ компенсувальним засобом для оформлення фрази, тому ці фонаційні засоби можуть розглядатися або як маргінальний випадок у паралінгвістиці, що виходить за межі висловлювання, але перебуває в межах самої мови, або як немовний і непаралінгвістичний засіб. Варто вказати, що ці характеристики комунікації надзвичайно поширені і фактично завжди наявні навіть у нейтральній функції (на основі опозиції в кожному висловлюванні).

Стійкі вирази на зразок дзвонити зубами (1) тремтіти від холоду, страху; 2) не мати чого їсти, голодувати); зуб на зуб не потрапляє (хтонебудь тремтить від великого холоду або з переляку); клащати зубами (1) дуже мерзнути; 2) вороже, недоброзичливо і т. ін. ставитися до когонебудь; 3) прагнути домогтися, досягти і т. ін. чого-небудь); цокотіти (цокотати, иокати) зубами (тремтіти від холоду, страху) у первинному значенні називають фізіологічний стан холоду або страху. Тремтіння покращує притік крові до тіла та ії інтенсивне перетікання судинами, що дозволяє створити „теплову подушку” для організму - ці реакції відбуваються при низькій температурі. А коли людина чогось лякається, то тремтіння характеризує готовність м'язів до втечі або нападу. Звичайно, така „наївна” анатомія (за О. В. Урисон) має своє відображення в мові, свідчить про особливості світогляду мовців. Звук, який лунає при стукові зубів, розглядається в паралінгвістиці як диференціатор фізіологічних 
реакцій $[4$, с. 35]; є парамовним елементом як і голос, тон, кінема, адже $\epsilon$ додатковим до мовного звукового коду, задіяний у процесі мовної комунікації та здатний передавати смислову інформацію (інколи людині досить поцокотіти зубами аби комунікат зробив відповідні висновки про іiі емоційно-фізіологічний стан).

Інші значення виникають на тлі інших соціально зумовлених, внутрішньомотивованих чинників як переосмислення міжособистісних стосунків 3 орієнтацією на символічність людських органів. Наприклад: вторинні значення фразеологізму клацати зубами називають ті поведінкові акти, які сприяють становленню особистості в соціальній групі, утвердженню свого Я, досягненню ідеалів та цілей тощо. Філогенетично це пояснюється важливістю зубів для первісної людини, тією роллю, яку вони виконували в процесі еволюції.

Фразеологічні одиниці, які „озвучують” голосову поведінку носія мови, функціонують у процесі комунікації не лише як мовні елементи для передачі інформації, смислів, ідей. У такому плані вони є транслятором ментальності народу, зберігають у своїй структурі голос не однієї, конкретної людини, а етносу загалом з його неповторними інтонаціями і переживаннями.

\section{Література}

1. Жайворонок В.В.Знаки української етнокультури : словник-довідник / Жайворонок Віталій Вікторович. - К. : Довіра, 2006. - 703 с.

2. Ильин Е. П. Эмоции и чувства / Евгений Павлович Ильин. - [2-е изд.]. - СПб., 2007. $-783 \mathrm{c}$.

3. Колшанский Г. В. Паралингвистика / Геннадий Владимирович Колшанский. [2-е изд.]. - М. : КомКнига, 2005. - 96 с.

4. Крейдлин Г. Е. Невербальная семиотика : [монография] / Геннадий Ефимович Крейдлин. - М. : „Новое литературное обозрение”, 2002.

5. Словник фразеологізмів української мови [уклад. В. М. Білоноженко та ін.] К. : Наукова думка, 2003. - 1104 с.

Стаття надійшла до редакиіï 04.10.2010 p. 